\section{How to press}

\section{the point}

\section{Roland Pease}

Hitting the Headlines: a Practical Guide to the Media. By Stephen White, Peter Evans, Chris Mihill and Maryon Tysoe. British Psychological Society: 1993. Pp. 144. £8.99.

WHEN the British public woke up at the end of last year to find that the Universe had been taken over by billions of black holes, it was not some malignant extraterrestrial that had been at work. Rather, it was the power of the press release, revealed in glorious Technicolor.

Mike Hawkins's interesting but unexceptional paper on dark matter in Nature (366, 242-245; 1993) would have drawn little attention had not the British Science and Engineering Research Council, just weeks before its institutional demise, put out a sensational invitation to the science press corps to learn the "answer to cosmology's biggest mystery", suggesting "large numbers of black holes" could be "the dominant component of the Universe".

For science writers, the story was a dream - 'sexy', straightforward in concept and with an easy-to-grasp bottom line. Mike Hawkins's willingness to say in public what others would rather keep between consenting professionals in the privacy of the coffee room was a key to the story's popularity. But for many scientists the episode epitomized all that is dangerous in tangling with the media - the tendency to sensationalism, superficiality and irresponsibility.

Finding the fine line between getting publicity for science and exposing it to ridicule is what Hitting the Headlines is all about. The first author, Stephen White, is director for information for the British Psychological Society, which has a long record of helpful and stimulating stories for the British media. The other three are professional science journalists. Together, they have assembled a nutsand-bolts picture of the British press and broadcasting media, how to deal with them, and how to use them. Most of the lessons - on preparing press releases, handling interviews, writing articles apply anywhere in the world.

If there's a moral to be drawn from the book, it's encapsulated in two rules the authors put forward: "the media knows exactly what it wants from you"; and "you have to put yourself in their hands". The point is that science journalists know who they are writing for, or broadcasting to, and at what level to pitch the story. Their very purpose is to report the latest (and best) in science. And they hate inaccuracy and irresponsibility as much as anyone: it does tham no good with their peers or their sources.

If they have a hard time, it's because for every Mike Hawkins who might be accused of overselling his results, there are many more scientists who will crush a good story by being unable to speak plainly to the press. Scientists, used to caution and qualification when speaking to their colleagues, find it hard to drop the habit when dealing with the broader public; jargon becomes such second nature they don't realize they're using it. (Even a simple term such as amplification can cause problems, showing how cultures can be divided by a common language. Any biologist will talk happily about amplifying genes, for example. But most people will be quite perplexed by the concept can you really make genes louder?)

The common complaint is that there's not enough science reported in the media. The authors of Hitting the Headlines argue that coverage is really very reasonable, given the vast range of human activity for the papers and broadcasters to choose from. Nonetheless, they have also prepared an easy and readable prescription for improving matters. Over to you. . .

Roland Pease is with the Science Unit, $B B C$ World Service, Bush House, London WC2B $4 P H$, UK.

\title{
Getting into deep water
}

\section{Martin Angel}

Global Marine Biological Diversity: A Strategy for Building Conservation into Decision Making. Edited by Elliott A. Norse. Island Press: 1993. Pp. 383. $\$ 50$ (hbk), $\$ 27.50$ (pbk); UK distributors: Earthscan, £24.95 (pbk).

MAINTENANCE of diversity and sustainable development have become the two central tenets of world conservation. Both appeared as major objectives in the first World Conservation Strategy, but there was a third in the original strategy, the

\section{IMAGE UNAVAILABLE FOR COPYRIGHT REASONS}

Hot spot - hydrothermal vent community.

conservation of ecological process, which has become increasingly overlooked. Yet the importance of the roles played by abiotic and biotic ocean processes in global geochemical budgets probably makes this third tenet the most relevant to ocean conservation. Compared with terrestrial ecosystems, oceanic ecosystems are very different in their structure and function. For example, there are more than a million species of insects known from the terrestrial realm, but fewer than 2,000 species of their marine counterparts, the copepods. The differences in functioning become accentuated once the depth becomes too great for the seabed to influence processes within the euphotic zone, so that the dominant factors influencing the ecosystems are hydrodynamic.

This book, sadly like all the other strategic documents on biodiversity, almost completely overlooks the 51 per cent of the Earth's surface that is covered by water 3,000-6,000 metres deep. There is no mention of ocean trenches. Hydrothermal vents are mentioned because of their strange and prolific ㅊ⿺ㄹ communities, based on chemosynthetic production. But the species-richness of these communities is low relative to the surrounding i barren regions. More new 은 species of nematode worms and foraminiferans have (D) been found in a couple of cubic centimetres of abyssal sediment from the North Atlantic than from all the vents investigated so far. There is no mention that each week the world's vents emit more heavy metals than industries throw away globally; does this suggest possible alternative waste disposal policies?

On the evidence of this book the conservation movement seems too divorced from the scientific base from which must come the knowledge it seeks, the technology it requires for monitoring and the ability it needs to understand change and to predict ecosystem response. This is a strategy for a static world, a world in which any change is bad and any change is the result of human activities. Present community structure depends on its history and resilience to change, but how 